\title{
techanics
}

\section{New possibilities for in situ CT analysis of additive manufactured samples}

\author{
Grzegorz Ziółkowski \\ grzegorz.ziolkowski@pwr.edu.pl | 이 http://orcid.org/0000-0002-9031-1528 \\ Grzegorz Treter \\ grzegorz.treter@pwr.edu.pl | 인.tp://orcid.org/0000-0001-9992-231X \\ Emilia Tokarczyk \\ e.tokarczyk19@gmail.com | ㅇ http://orcid.org/0000-0001-5293-8912
}

\section{Patrycja Szymczyk-Ziótkowska}

Scientific Editor: Andrzej Sobczyk, Cracow patrycja.e.szymczyk@pwr.edu.pl | (0) http://orcid.org/0000-0001-7742-7182 University of Technology Technical Editor: Matgorzata Sikora, Cracow University of Technology Press Language Editors: Michael Fyall, The Department of Foreign Languages, Wroctaw University of Science and Technology Typesetting: Małgorzata Murat-Drożyńska, Cracow University of Technology Press

Received: October 16, 2019

Accepted: September 9, 2020

Copyright: @ 2020 Ziótkowski, Treter, Tokarczyk, Szymczyk-Ziótkowska. This is an open access article distributed under the terms of the Creative Commons Attribution License, which permits unrestricted use, distribution, and reproduction in any medium, provided the original author and source are credited.

Data Availability Statement: All relevant data are within the paper and its Supporting Information files.

Funding: Supported by the Statutory Grant of Wroclaw University of Science and Technology (Grant No. 0402/0074/18).

Competing interests: The authors have declared that no competing interests exist.

Faculty of Mechanical Engineering, Centre for Advanced Manufacturing Technologies (CAMT/FPC), Wroclaw University of Science and Technology

\begin{abstract}
Industrial Computed Tomography (CT) is a broadly used measurement method allowing for quality control of objects produced using additive manufacturing methods. The combination of tensile tests and simultaneous 3D imaging of the behavior of an object under a particular force (i.e. in situ examination - during the process) significantly broadens the possibilities of analyzing objects with a complex internal geometry. The purpose of this paper is to present the author's project of a mini testing machine, to verify its functioning with regards to a static testing machine, and to present the initial in situ examination results for polymer samples.
\end{abstract}

Tokarczyk, E., Szymczyk-Ziótkowska, P. (2020). New possibilities for in situ CT analysis of additive manufactured samples. Technical Transactions, e2020028. https:// doi.org/10.37705/TechTrans/e2020028

Keywords: industrial computed tomography, mechanical properties, polymers, additive manufacturing 


\section{Introduction}

Industrial Computed Tomography (CT) is a broadly used measurement method allowing for the quality control of objects produced with additive manufacturing methods (Thompson, Maskery, Leach, 2016). The undoubted advantage of the method described in the paper is the possibility of carrying out non-destructive analysis of the internal and external geometry of examined objects with a resolution from a few to dozens of micrometers (Gapinski, Janicki, Marciniak-Podsadna, Jakubowicz, 2016). Apart from porosity analysis (Ziótkowski, Chlebus, Szymczyk, Kurzac, 2014), the detection of cracks, inclusions or discontinuity, and the dimensional control of manufactured geometry (Barciewicz, Ryniewicz, 2018), computed tomography is increasingly used in combination with tensile tests (Koruba, Karoluk, Ziótkowski, Chlebus, 2018; Mertens et al., 2017) or compression tests (Jansson, Pejryd, 2019; Dhillon, Schneider, Kuhn, 2011). Conducting such tests is possible with the use of mini testing machines that are specifically adjusted to work in CT measurement conditions (Hufenbach et al., 2012; De Chiffre et al., 2014). The combination of tensile tests and simultaneous 3D imaging of the behavior of an object under a particular force (i.e. in situ examination - during the process) significantly broadens the possibilities of analyzing objects with a complex internal geometry (i.e. scaffolds) (Pawlak et al., 2015; Szymczyk, Ziótkowski, Junka, Chlebus, 2018). Such a solution allows the development of individualized implants with a unique internal geometry. The implants can be adjusted to both a specific anatomical and physiological structure and to real loads caused by daily functioning. The purpose of this paper is to present the author's project of a mini testing machine, to verify its functioning with regards to a static testing machine, and to present the initial in situ examination results for polymer samples with a complex geometry which were manufactured using the FFF method (Fused Filament Fabrication).

\section{Mini testing machine}

The mini testing machine was designed in a way that allows it to be placed in the measuring chamber of a CT system, and for a full 3D reconstruction, including the $360^{\circ}$ rotation of the object (Fig. 1a), to be conducted. The construction of the mini testing machine is characterized by its compact structure, low weight (up to $10 \mathrm{~kg}$ together with the examined object), and its module design that allows for measurements to be conducted with a high resolution.

The machine body in which the tested sample is placed and reconstructed is the main element that is exposed to the highest loads. Therefore, this part was made of a fiberglass composite - a material with good tensile features and relatively low $\mathrm{X}$-ray absorption. Two rims made with stainless steel were joined to the tube using the molder-glued joint. The modular system which transfers compressive and tensile loads is developed in a way that it can be freely modified. Such modification depends on the size of the examined sample or the required CT resolution for the reconstruction.

The main element of the drive unit is the servomotor S-1 FL6 (produced by Siemens Company) with the SINAMICS V90 controller. This solution allows for precise regulation of the engine's rotational speed during variable load. Two worm gears were used in the drive unit, which allowed for the engine's axis orientation to be changed relative to the load screw of the lift. As a result, a firm and compact structure of the device was achieved, while at the same time maintaining the required working parameters. The mechanism used to generate tensile and compressive force is based on a screw mechanism with a movable cap, which is driven by an integrated worm gear. The testing machine allows for the conducting of examinations for samples with a diameter of $35 \mathrm{~mm}$ and a height determined by the resolution of the CT measurement. The range of loads is up to $5 \mathrm{kN}$, and the speed of force can increase from $0.01 \mathrm{~mm} / \mathrm{min}$ to $30 \mathrm{~mm} / \mathrm{min}$. 
Fig. 1. Diagram of the measuring system a) in situ loading device in the measuring chamber of the CT system, b) cross-section through an in situ loading device (by authors)

Fig. 2. Diagram of the mini testing machine's control system (Alitech, 2019; Mall.industry. siemens, 2019)
Fig. 3. a) Designed specimens for research, b) Designed internal geometry with linear filling at a $45^{\circ}$ angle: external frame is marked in red, linear filling is marked in yellow (by authors)
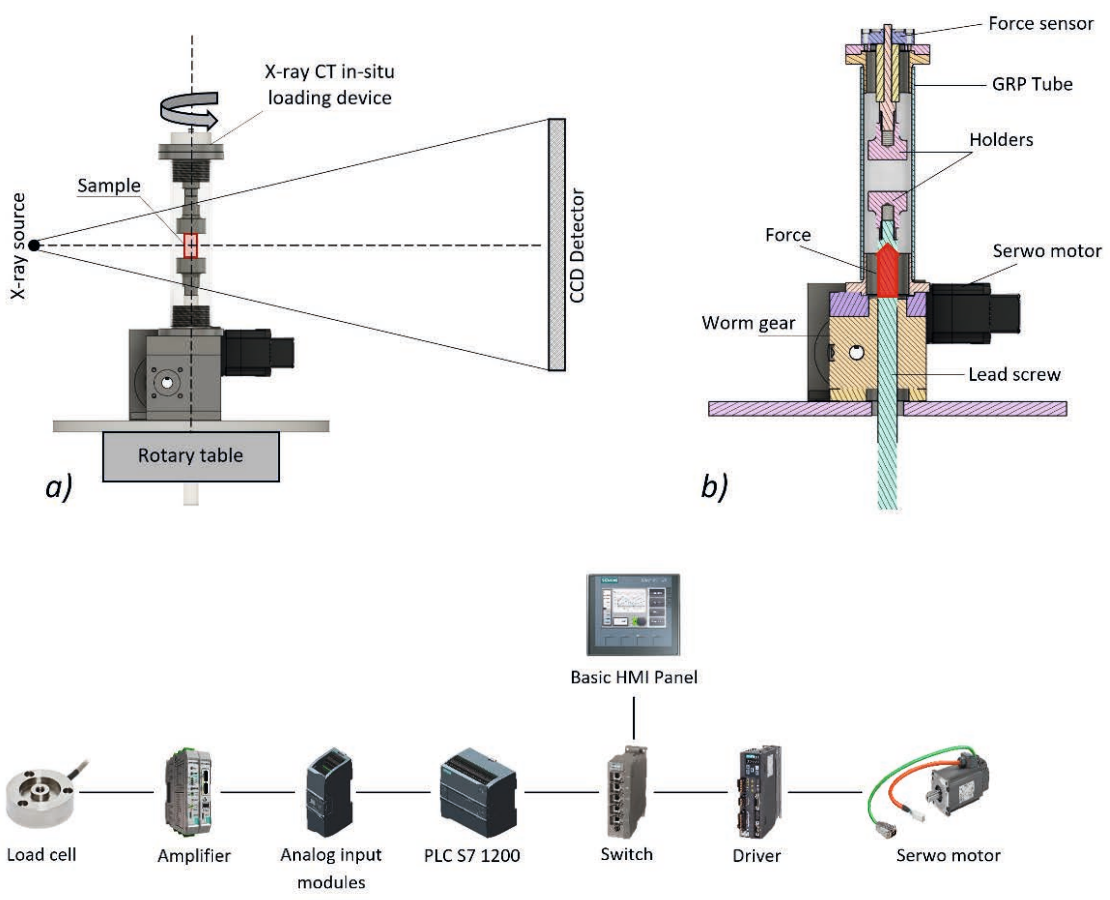

A force sensor produced by Burster Company (model 8524-6010 with a range of up to $10 \mathrm{kN}$ ) was used as the measurement element. This device is characterized by a non-linearity coefficient in the range below $0.25 \%$. The strengthening and conversion of a signal's reading from the force sensor to the voltage (or current) standard was gained by using the Burster model 9250 amplifier.

As the control unit, a Siemens S7-1200 PLC controller expanded with a 13-bit analog I/O module was used. The mini testing machine is controlled by the operator's panel HMI (Fig. 2). All the elements described above are a part of the control unit and are connected according to the industrial standard PROFINET. Such a solution makes the communication of every device possible in an internal network.

\section{Test samples}

In order to evaluate the test results obtained with the use of the mini testing machine, verification tests were carried out on samples in the form of cylinders with a diameter of $15 \mathrm{~mm}$ and a height of $30 \mathrm{~mm}$. The samples had linear filling (with $45^{\circ}$ angle) on the level of $25 \%$ of the material's volume. Every sample had an external frame with a thickness of $0.4 \mathrm{~mm}$, made as one contour of the printing head (Fig. 3).

a)
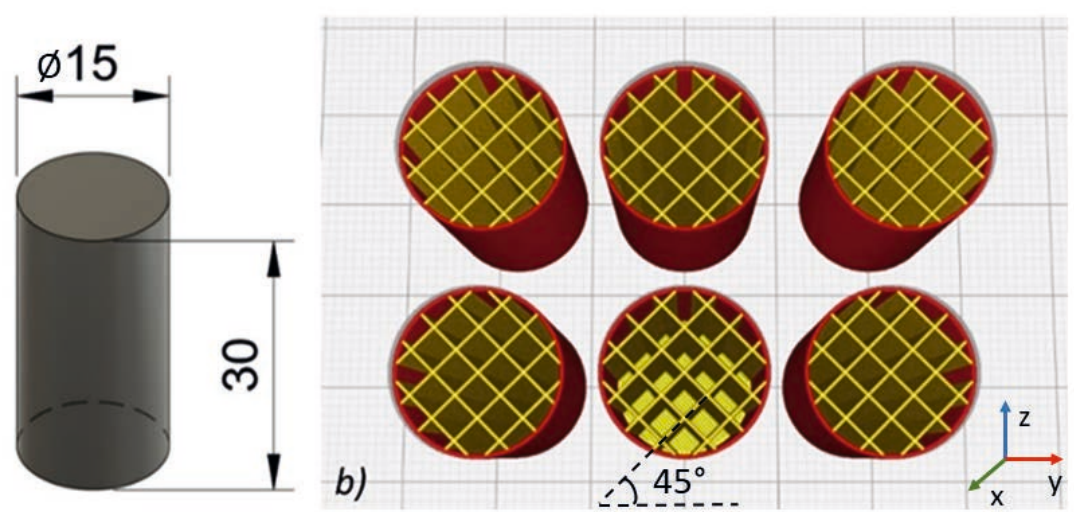
The shape and dimensions of the manufactured samples were developed according to the PN-EN ISO 604:2004 standard (Polski Komitet Normalizacyjny, 2006). The CAD models of the test samples were prepared using Autodesk Fusion 360 software and then saved to STL format. Such a format enabled them to be loaded into the software, which in turn allowed executive files to be generated for the Ultimaker 2+ device that works using FFF additive technology. To create the executive files, Cura v. 4.00 software was used. All the samples were manufactured from thermoplastic material PLA (Pro 3D), in the form of filament, using the same parameters as for the manufacturing process (Tab. 1).

Table 1. Parameters used in the FFF process of the PLA samples

\begin{tabular}{|c|c|c|c|c|}
\hline $\begin{array}{c}\text { Working head } \\
\text { temperature }\left[{ }^{\circ} \mathrm{C}\right]\end{array}$ & $\begin{array}{c}\text { Work platform } \\
\text { temperature }\left[{ }^{\circ} \mathrm{C}\right]\end{array}$ & $\begin{array}{c}\text { Nozzle diameter } \\
{[\mathrm{mm}]}\end{array}$ & $\begin{array}{c}\text { Layer height } \\
{[\mathrm{mm}]}\end{array}$ & $\begin{array}{c}\text { Filament } \\
\text { diameter } \\
{[\mathrm{mm}]}\end{array}$ \\
\hline 210 & 60 & 0.4 & 0.06 & 2.85 \\
\hline
\end{tabular}

For the research described in this paper, 13 identical samples were produced. Twelve samples were used for the examination, which included a static compression test. For the $\mathrm{CT}$ reconstruction during the in situ static compression test using variable load values, one randomly chosen sample was taken.

\section{Verification of the mini testing machine}

To evaluate the examination results obtained with the use of the mini testing machine and to verify the correctness of the device, it was decided to conduct a comparative test in order to confirm that the measurement method is appropriate for the defined usage. The referential tests were carried out using the INSTRON 3384 testing machine. A measurement head, weighing $150 \mathrm{kN}$ and with $0.5 \%$ of accuracy, and compression testing discs were used. During the tests, regardless of the device used, the samples were initially loaded with $100 \mathrm{~N}$ and the measurement was made at a speed of $0.5 \mathrm{~mm} / \mathrm{min}$. To compare the results given with the described methods and to determine the precision of the measurements, a variation coefficient RSD (relative standard deviation \%) was used. The results of testing are presented as graphs that show the increasing force in relation to the displacement. Figure 4 shows an example of a compression curve given for each described device.

It can be seen that the shape and flow of both curves are similar. In addition, based on the conducted tests, it was revealed that the results from the mini testing machine correspond to the results from the commercial testing machine. The average value of the noticed load, which causes permanent deformation

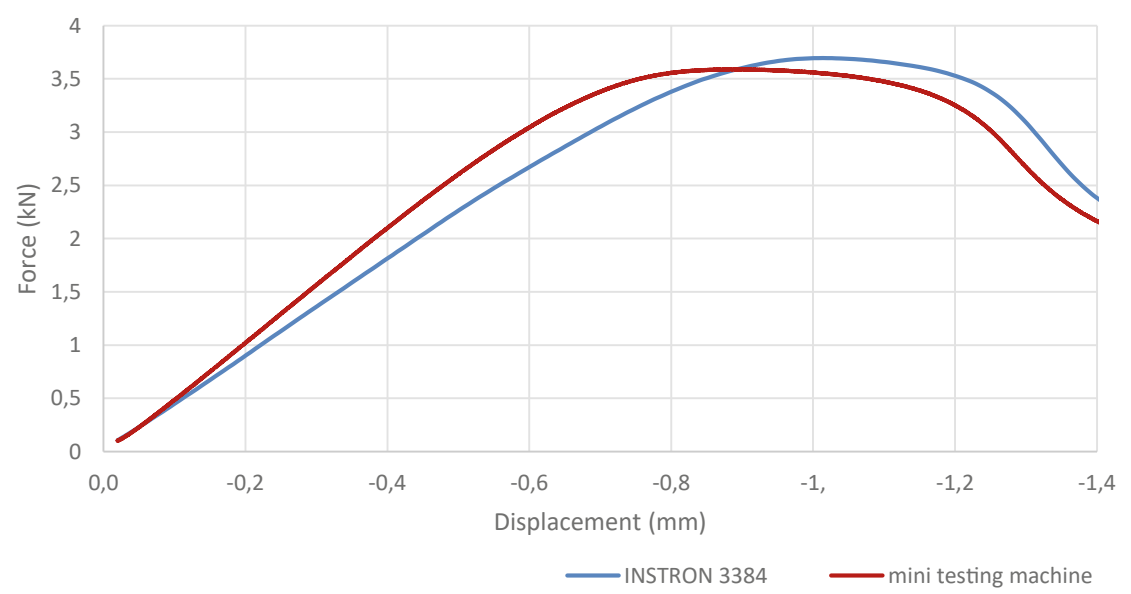

Fig. 4. Comparison of results obtained for loading samples from a) INSTRON 3384 testing machine, b) mini testing machine (by authors) 
Fig. 5. a) The in situ loading device integrated in the measuring system METROTOM 1500, b) the $\mathrm{X}$-ray image obtained for a load of $100 \mathrm{~N}, \mathrm{c}$ ) the $\mathrm{X}$-ray image obtained for a load of 2,900 $\mathrm{N}$ (by authors)
Fig. 6. Geometry deviations of the tested sample obtained for subsequent load levels (by authors) of the sample, is on the level of $3580 \pm 141 \mathrm{~N}$ for the mini testing machine and $3645 \pm 193 \mathrm{~N}$ for the INSTRON 3384 . The repeatability of the method, which is presented by the RSD coefficient, is at the level of $3.9 \%$ for the mini testing machine and $5.3 \%$ for the commercial testing machine. The value gained for the author's device shows the high repeatability level of the test results.

\section{In situ CT reconstructions}

The mini testing machine was integrated with the tomographic system METROTOM 1500 (Fig. 5a), which has an X-ray tube with a tungsten target, a maximum accelerating voltage of $225 \mathrm{kV}$ and flat panel detector $1024 \times 1024$ pixels. The parameters used during the CT reconstruction are shown in Table 2. Five CT reconstructions were made for the load levels of $100 \mathrm{~N}, 2,500 \mathrm{~N}$, $2,750 \mathrm{~N}, 3,000 \mathrm{~N}$, and 2,900 N. Every reconstruction was done in the conditions of constant interaction of the determined force, without unloading the sample.

Table 2. CT measurement parameters used in the in situ reconstruction

\begin{tabular}{|c|c|c|c|c|c|}
\hline $\begin{array}{c}\text { Voltage } \\
{[\mathrm{kV}]}\end{array}$ & $\begin{array}{c}\text { Current } \\
{[\mu \mathrm{A}]}\end{array}$ & $\begin{array}{c}\text { Int. Time } \\
{[\mathbf{s}]}\end{array}$ & $\begin{array}{c}\text { Voxel } \\
\text { size[ }[\mu \mathrm{m}]\end{array}$ & Projections & $\begin{array}{c}\text { Filters Cu } \\
{[\mathrm{mm}]}\end{array}$ \\
\hline 220 & 120 & 2 & 39.68 & 900 & 0.5 \\
\hline
\end{tabular}
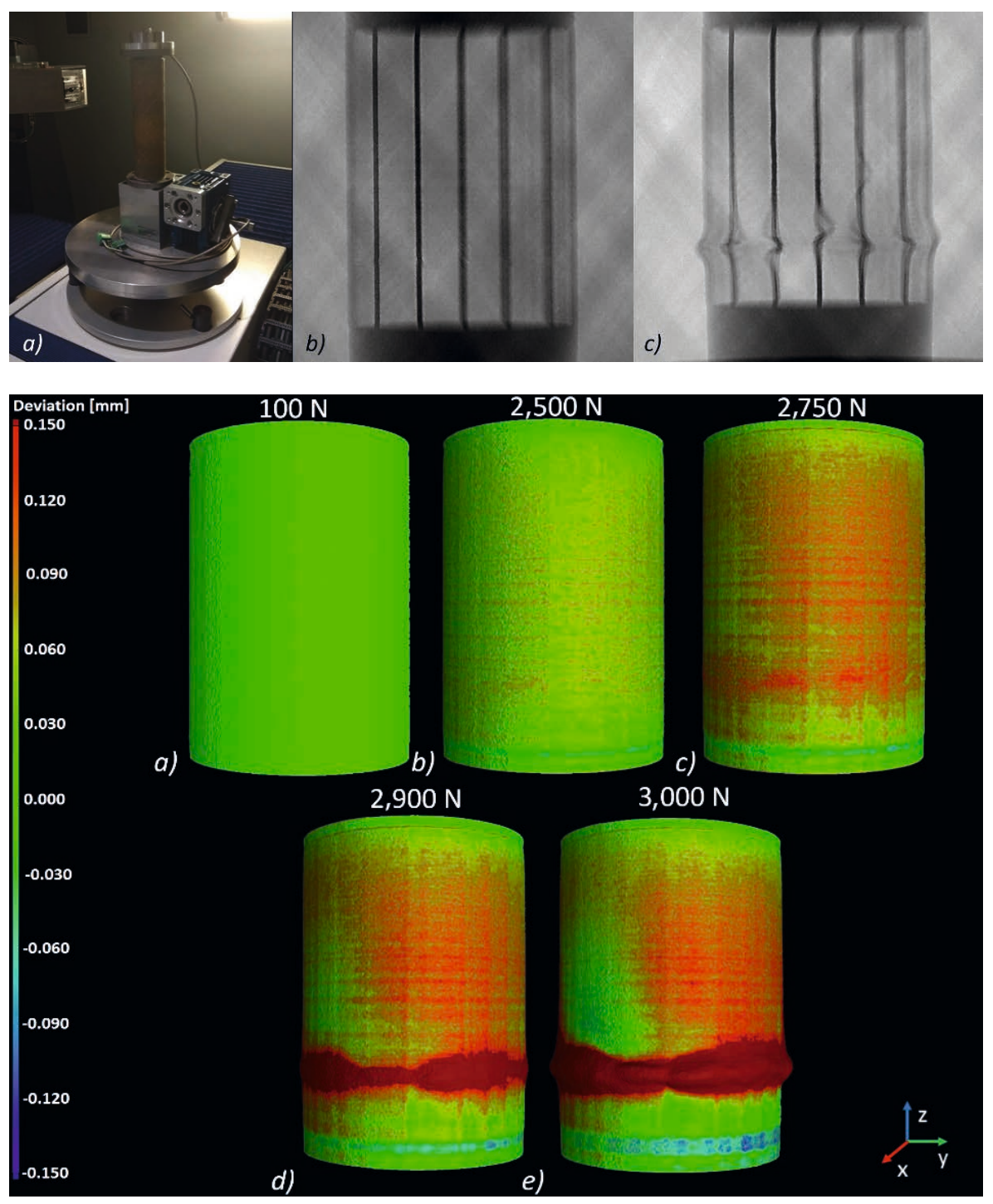
Exemplary X-ray photos for the samples loaded with $100 \mathrm{~N}$ and 2,900 $\mathrm{N}$ are shown in Figure $5 b$ and $5 c$.

The X-ray pictures show the condition of the sample and the deformation of its internal structure in a 2D cross-section, which enables the impact of the given force on the sample's internal geometry to be assessed. The quantitative evaluation may be done based on the comparison of the $3 \mathrm{D}$ volumetric models given in the CT reconstruction to different states of loading. Figure 6 shows, in the form of a color map, deviations in the geometry, which result from the sample being loaded with a force of $100 \mathrm{~N}$ (Fig 6a), and successively with a force ranging from $2,500 \mathrm{~N}$ to $3,000 \mathrm{~N}$ (Fig. $6 \mathrm{~b}-\mathrm{e}$ ).

The force of 2,750 $\mathrm{N}$ caused the formation of geometric variables located in the bottom part of the sample. Further loading caused the enlargement of the deformation space and permanent deformation of the sample. The loaded sample had a lower level of durability than the samples described in point 4.

This phenomenon may be explained by the existence of heterogeneities in the material layer (red arrow no. 2) that was laid during the FFF manufacturing process. The material discontinuities that can be seen in Figure 7a reduce the mechanical properties of the analyzed structure, and are also the place where the largest deformations of the internal and external structure are concentrated. This can be seen in the following figures that show the 3D view of the internal geometry of the sample under the initial load (Fig. 7b) and during the maximal deformation (Fig. 7c). The geometry variables are shown as a map of colors. The changes for further levels of loading in the planes marked with red arrows in Figure 7 are shown as cross-sections in Figure 8.

The changes in the internal geometry of the analyzed sample, exposed during the in situ tests, allow for evaluation of the influence of the used loading
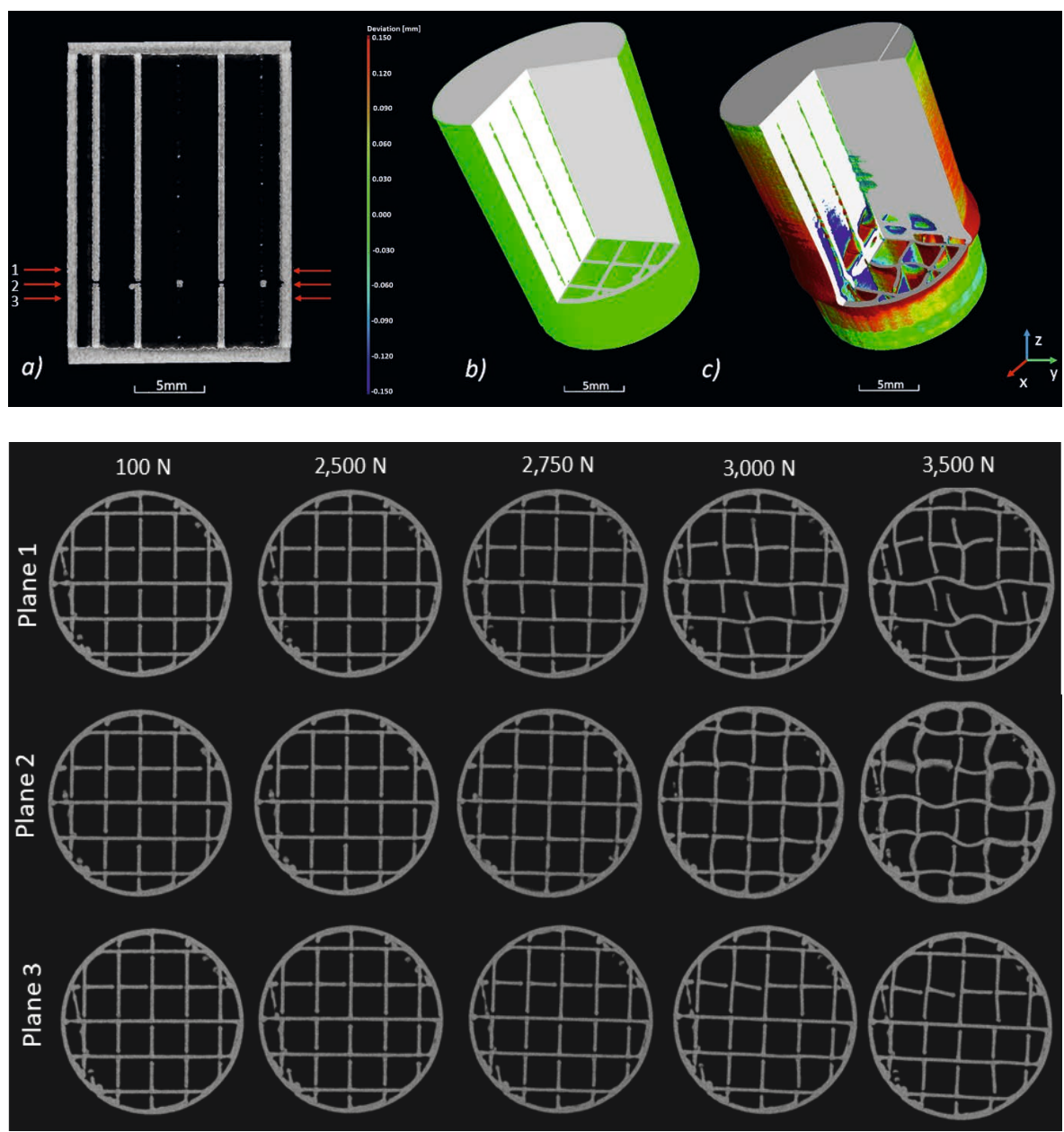

Fig. 7. a) Cross-section through the tested sample (defects appearing on one of the layers of the sample are marked with the red arrow no. 2 , b) volumetric model obtained for a load of $100 \mathrm{~N}, \mathrm{c}$ ) volumetric model obtained for a load of $2,900 \mathrm{~N}$ (by authors)
Fig. 8. Cross-sections (marked with red arrows in Fig. 7a) of the tested sample subjected to loads with different levels of forces (by authors) 
on the functional features of complex structures. This kind of analysis enables the identification of areas that are particularly vulnerable to the formation of permanent deformations. Moreover, it gives the opportunity to optimize both the manufacturing process and the construction of the final product.

\section{Conclusion}

The device presented in this paper can be successfully implemented for in situ testing examinations when using technical computed tomography. The modular design of the mini testing machine allows the device to be adopted to different sample sizes or to a different types of tomographic systems. The following conclusions can be drawn:

Comparison of the test results obtained using a static compression test with those obtained using a commercial testing machine reveals a high level of convergence. Further development works on the mini testing machine will be connected with the enlargement of examination possibilities of mechanical tests, including a static tensile and bending test.

The preliminary research of the static in situ compression test for the sample made of thermoplastic material (PLA) described in this paper allowed the functional properties of spatial structures with a complex internal geometry to be evaluated.

The obtained results enable the behavior of a designed structure during loading to be fully characterized. This in turn may be a basis for optimizing the internal structure's geometry in order to adjust the construction to specific mechanical and functional requirements.

\section{References}

Alitech (2019). Retrieved from https://alitech.com.pl (date of access: 2019/08/30).

Barciewicz, M., Ryniewicz, A. (2018). Computed tomography as a quality control technique in the $3 \mathrm{~d}$ modelling of injection- moulded car system components. Czasopismo Techniczne, 9(9), 189-200. https://doi.org/10.4 467/2353737XCT.18.140.8979

De Chiffre, L., Carmignato, S., Kruth, J.P., Schmitt, R., Weckenmann, A. (2014). Industrial applications of computed tomography. CIRP Annals - Manufacturing Technology, 63(2), 655-677. https://doi.org/10.1016/j. cirp.2014.05.011

Dhillon, A., Schneider, P., Kuhn, G. (2011). Analysis of sintered polymer scaffolds using concomitant synchrotron computed tomography and in situ mechanical testing. Journal of Materials Science: Materials in Medicine, 22(12), 2599-2605. https://doi.org/10.1007/s10856-011-4443-z

Gapinski, B., Janicki, P., Marciniak-Podsadna, L., Jakubowicz, M. (2016). Application of the computed tomography to control parts made on additive manufacturing process. Procedia Engineering, 149, 105-121. https://doi. org/10.1016/j.proeng.2016.06.645

Hufenbach, W., Böhm, R., Gude, M., Berthel, M., Hornig, A., Ručevskis, S., Andrich, M. (2012). A test device for damage characterisation of composites based on in situ computed tomography. Composites Science and Technology, 72(12), 1361-1367. https://doi.org/10.1016/j.compscitech.2012.05.007

Jansson, A., Pejryd, L. (2019). In-situ computed tomography investigation of the compression behaviour of strut, and periodic surface lattices. In 9th Conference on Industrial Computed Tomography (pp. 1-7). 
Koruba, P., Karoluk, M., Ziółkowski, G., Chlebus, E. (2018). Application of thermal imaging system for prediction of fatigue crack initiation in Ti6Al-4V fabricated by EBM. In 14th Quantitative InfraRed Thermography Conference (pp. 141-147). https://doi.org/10.21611/qirt.2018.p36

Mall.industry.siemens (2019). Retrieved from https://mall.industry.siemens. com/ (date of access: 2019/08/30).

Mertens, J.C.E., Henderson, K., Cordes, N.L., Pacheco, R., Xiao, X., Williams, J.J., Chawla N., Patterson., B.M. (2017). Analysis of thermal history effects on mechanical anisotropy of 3D-printed polymer matrix composites via in situ X-ray tomography. Journal of Materials Science, 52(20) 12185-12206. https://doi.org/10.1007/s10853-017-1339-4

Pawlak, A,. Szymczyk, P., Ziolkowski, G., Chlebus, E., Dybala, B. (2015). Fabrication of microscaffolds from Ti-6Al-7Nb alloy by SLM. Rapid Prototyping Journal, 21(4) 393-401. https://doi.org/10.1108/RPJ-102013-0101

Polski Komitet Normalizacyjny (2006). Tworzywa sztuczne - Oznaczanie właściwości przy ściskaniu PN-EN ISO 604.

Szymczyk, P., Ziótkowski, G., Junka, A., Chlebus, E. (2018). Application of Ti6Al7Nb alloy for the manufacture of biomechanical functional structures (BFS) for custom-made bone implants. Materials, 11(6), 971. https://doi.org/10.3390/ma11060971

Thompson, A., Maskery I., Leach, R.K. (2016). X-ray computed tomography for additive manufacturing: A review. Measurement Science and Technology, 27, 072001. https://doi.org/10.1088/0957-0233/27/7/072001

Ziótkowski, G., Chlebus, E., Szymczyk, P., Kurzac J. (2014). Application of X-ray CT method for discontinuity and porosity detection in 316L stainless steel parts produced with SLM technology. Archives of Civil and Mechanical Engineering, 14(4), 608-614.https://doi.org/10.1016/j.acme.2014.02.003 


\title{
Nowe możliwości analizy CT in situ próbek wytwarzanych metodą przyrostową
}

\begin{abstract}
Abstrakt
Tomografia komputerowa (CT) jest obecnie powszechnie stosowaną metodą pomiarową pozwalającą na kontrolę jakości obiektów wytwarzanych z wykorzystaniem technologii przyrostowych. Połączenie badań wytrzymałościowych z jednoczesnym trójwymiarowym obrazowaniem zachowania się obiektu pod wpływem działania określonej sity (tzw. badania in situ - w procesie) znacznie rozszerza możliwość analizy obiektów o złożonej strukturze przestrzennej. Celem niniejszej pracy jest przedstawienie autorskiego projektu minimaszyny wytrzymałościowej oraz weryfikacja poprawności jej działania w odniesieniu do komercyjnych rozwiązań, a także przedstawienie wstępnych wyników badań in situ dla przestrzennych próbek polimerowych.
\end{abstract}

Stowa kluczowe: techniczna tomografia komputerowa, właściwości mechaniczne, polimery, wytwarzanie przyrostowe 